\title{
Using Whatsaap As A Learning Media In Teaching Reading
}

\author{
Martina Napratilora ${ }^{1}$, Hendro Lisa ${ }^{2}$, Indra Bangsawan ${ }^{3, *}$ \\ ${ }^{1}$ Pendidikan Guru Madrasah Ibtidaiyah, STAI Auliaurrasyidin, Tembilahan Riau, Indonesia \\ ${ }^{2}$ Ekonomi Syariah, STAI Auliaurrasyidin, Tembilahan Riau, Indonesia \\ ${ }^{3}$ Pendidikan Islam Anak Usia Dini, STAI Auliaurrasyidin, Tembilahan Riau, Indonesia \\ *Corresponding author: napratiloramartina@gmail.com \\ *Corresponding author: hendro.lisanew@ gmail.com \\ *Corresponding author: indra23bangsawan@gmail.com
}

\begin{abstract}
Abstrak
Dalam mendukung keberhasilan proses pembelajaran dan pengajaran, para pendidik tentunya tidak asing lagi dengan penggunaan berbagai media pembelajaran dalam pembelajarannya seperti media audio dan visual atau menggunakan cards, kertas karton, stik, maupun gambar. Saat ini dunia lagi dilanda musibah yang mengakibatkan ssemua lapisan masyarakat harus terkena social distancing. Demikian juga dengan dunia pendidikan. Para siswa tidak diperbolehkan melakukan pendidikan di sekolah demi terhidar dari covid-19 atau menekan penyebaran covid-19. Agar pendidikan tetap bias dilakukan maka pemerintah menganjurkan para pendidik untuk melaukan pengajaran secara daring menggunakan technology. Technology yang terus berkembang mengakibatkan bermunculannya aplikasi-aplikasi yang bias digunakan dengan smart phone seperti ruang guru, zoom, google meet, whatsapp, facebook dan yang lainnya. Diantara semua aplikasi tersebut whatsapp adalah aplikasi yang terpopuler dan mudah digunakan. Melalui whatsapp kita bisa mengirim foto, audio, dokumen, video bukan hanya secara individu namun bias juga dilakukan secara group dengan berbagai kemudahan yang tersedia difitur whatsapp maka sangat layaklah para pendidik dan siswa menggunaka nwhatsapp sebagai salah satu media pembelajaran apalagi dimasa covid-19 ini.
\end{abstract}

Kata Kunci: Pengajaran, Media Pembelajaran, Whatsapp

\section{INTRODUCTION}

Today is a digital era. In this era, technology development gives effect to every aspect of human life. Technology development in the modern digital era causes much growth up of media social. WhatsApp (WA) is one of the most popular social media which is used by Indonesian people. Almost all human use WhatsApp as daily social media (Khusaini, Suyudi, Winarto, \& Sugiyanto, 2017).It makes easy interaction among people through messaging, pictures, audio, document, and the unique one of WhatsApp is a group discussion. 
WhatsApp is one of the online communicating tools on the smartphone. The smartphone is so easy to use and simple form. It makes many people use Smartphone in daily life to communicate with each other. The people can communicate with each other by sending a message, video, audio, photo, topic discussion, and create a group discussion/ group chat with a purpose. The maximal member of a group chat on WhatsApp is 256 members.

Big WhatsApp advantages in supporting human communicating do not use and apply yet in the field of education well especially in teaching reading comprehension. WhatsApp utilization in teaching reading comprehension needs to apply as a teaching and learning media in a digital era. Facilitating the process of teaching and learning English, the teacher can use WhatsApp as instructional media (Kheryadi, 2017). WhatsApp Application Messenger is very potential media in teaching (Jumiatmoko, 2016). It means that English teachers are able to apply WhatsApp as one of the media in teaching reading comprehension.

In improving students' reading comprehension, the English teachers have tried to use some methods and approaches on teaching and learning process but the students' reading skill is still unsatisfied. English teachers have applied methods and approaches in teaching but the result shows that no one of them is $100 \%$ successful to improve students' reading comprehension. It is difficult for an English teacher to manage the time or spend much time teaching reading especially to develop students' reading comprehension in the classroom with limited time (George, 2018).

Reading is an activity to get knowledge and information from written language like words, symbols, and pictures. In addition, reading is getting meaning from printed words and making sense for different purposes like for getting new knowledge, for pleasure, and for interest (Linse \& Nunan, 2005). The key areas of reading like who read, how we read, what we read as well as where we read have to base on the reading purposes (Pyrhonen, 2018). So, reading comprehension is very important to be mastered by the students and also the teacher to catch important information from reading sources.

Reading comprehension can be increased by utilizing the technology application. Technological digital advance has much potential as an instructional tool in literacy education. The technology-based tool gives many advantages to the user one of them is increasing students' reading skill (Biancarosa \& Griffiths, 2012). Today, WhatsApp is so popular technology application in daily life with many users in the world. As a social media network, WhatsApp can use to get information fast. In the context of teaching and learning process, WhatsApp is able to help the students to interact with each other by using English whenever and wherever. Besides that WhatsApp are able to help the students increase language skills like speaking, writing, reading and listening (D'Eca, 2003).

WhatsApp application is a smartphone application which functions to send and receive messages fast. WA is so easy and simple in applying for communicating that makes many people from different age, background, purpose use them in daily life. WA has some functions such as sending messages, picture, audio, video, document, and web 
address. By looking this functions and advantages of WA in communicating, these advantages are also utilized as a tool/media in teaching and learning English like sending English messaging, share English picture, English document, and English text materials. The user can send messages to individual or group in the form of text messages, photo, audio file, video file, and link of the web address to be accessed (Bouhnik \& Deshen, 2014).

The objectives of this study are to describe WhatsApp messenger as learning media in teaching reading comprehension and process how to use WhatsApp messenger as learning media in teaching reading comprehension.

\section{DISCUSSION}

\section{Reading Comprehension Definition}

Reading is a skill to get information from books, newspapers, magazines, journals, comics, novels, and the internet. Having reading skill needs more efforts like times to read and reading sources. Furthermore, reading refers to a complex process which includes analysis, coordination, and interpretation of several sources to get important knowledge and information (Scanlon, Anderson, \& Sweeney, 2010).

Understanding a reading text is not easy. Readers have to familiar with several reading components. They are(Snow, 2002):

1. Determining factual information

2. Determining the main idea

3. Determining reference

4. Enumerating inference

5. Making restatement

Besides that, a reader read a reading source with a purpose like to get information, knowledge, make a summary, finish homework, prepare presentation, enjoyment, and so on. Reading for an academic purpose has some aims as follows (M \& Kanchana, 2016):

1. Searching for information

2. Quick understanding

3. Learning

4. Combining information

5. Evaluating, comment, and use the information

6. General understanding or entertaining

A good reader is not only need reading skill but she/he needs to comprehend what she/he has read. That means that the reader is not only read the text but also comprehend the text.Reading comprehension is as the process of simultaneously extracting and constructing meaning through interaction and involvement with written language (Catherin, 2003). In other words, Comprehension of written English is accomplished with ease since students read language that is highly meaningful and relevant to their personal lives (Denis and Carol, 2008).

\section{WhatsApp Definition}


WhatsApp is created by CEO Jan Koum and Brian Acton in Mountain View of California (United States) in 2009 (M \& Kanchana, 2016). It is one of the most popular applications that are used by people in communicating with each other. Among online communication applications (FaceBook, Twitter, Instagram, Line, WhatsApp, and so on) WhatsApp is the most famous communication application. As many as $82 \%$ of users chose WhatsApp application to communicate with other (Kheryadi, 2017).WhatsAppmessenger can send and receive messages, videos, pictures, andaudios to individual or group easy and fast. It can be done using an internet connection. WhatsApp messenger is free in sending and receiving data from the users. Besides that, this application is so easy and simple to be used for Youngers until adult people( $\mathrm{M} \&$ Kanchana, 2016). WhatsApp messenger application gives many choices and facilitates to support teaching and learning activity which includes teaching reading comprehension.

WhatsApp messenger is very useful in teaching and learning activities, especially in teaching reading. The teachers are able to send the materials to the students whenever and wherever. Besides that, the teachers are also easy to inform the students about schedule changed or giving a reading task, additional task, homework, and assignment before starting the class. For the students, they are easy to give information to the teacher when they cannot attend the class and easy to follow the materials and tasks on the WhatsApp messenger group (Justina, 2016).

The students use WhatsApp with several aims and reasons as follows(M \& Kanchana, 2016):

1. Getting good information and easy to communicate with their friends.

2. Collecting common knowledge

3. Sharing feeling to friends and family

4. Spending time

5. Education purposes like doing homework and task.

6. Getting important news and up to date information such as science with related videos, audios, documents, and so on.

7. Increasing reading interested

8. Updating social issues.

\section{Ways in Using WhatsAppas a Learning Media in Teaching Reading Skill}

The ways to make WhatsApp messenger work as learning media as follows (Santrossa \& Castillo, 2017):

1. Rules making

The first step to use WhatsApp messenger is mentioning the guideline to the students, therefore they know what the teachers' hope to them. The vital thing is the students know what they do and how the teacher assesses them. Clear instruction about how to do the task is so essential to avoid students' confusing. The rules example: 


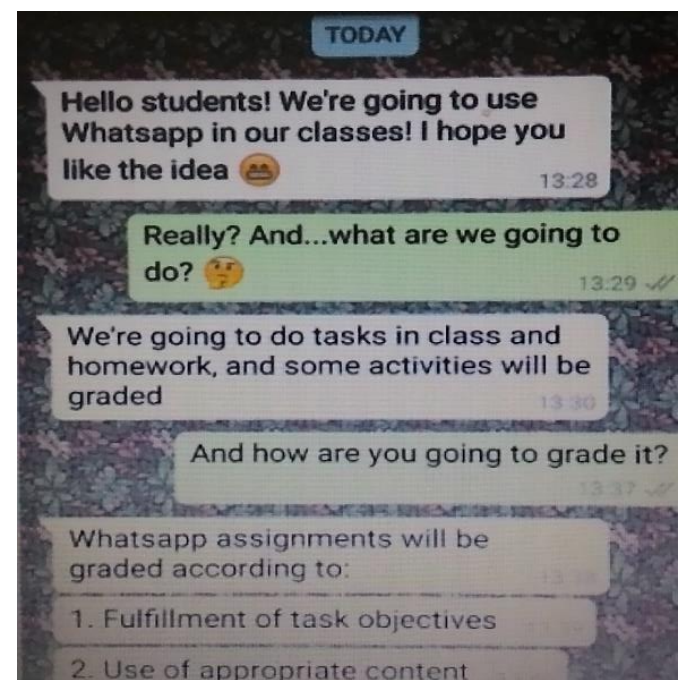

Taken from: https://ltsig.iatefl.org/whats-up-in-the-classroom-whatsapp/

\section{Group creating}

At the first meeting, the teacher and the students create a WhatsApp group with all students and the teacher as its members. The teachers need a "trial" how to use WhatsApp in the group to help the students understand with the process well. Besides that, the teachers are able to create a small group that consists of 4 until 5 students only and still include in the class of WhatsApp group. It for getting more personal assessment and improvement to the students and then change the members with other students.

3. Applying reading activities

The teacher can give different activities to the students like homework, extra activities for smartest students in the class, entertaining activities like funny text and so on. In this process, clear instruction is very necessary for the students in comprehending the task well. The reading activities instruction can be seen as bellows: 


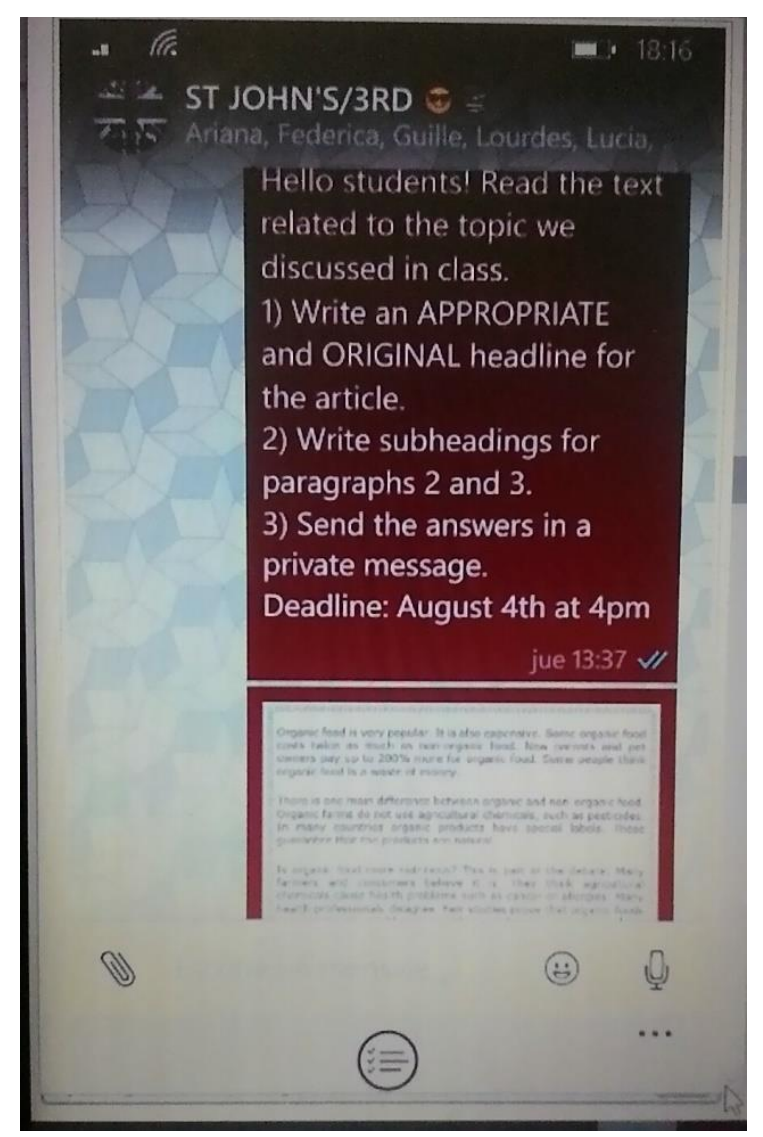

Taken from: https://ltsig.iatefl.org/whats-up-in-the-classroom-whatsapp/

4. Designing reading activities

The reading activities can be in the form of a document or reading text, electronic source, audio, video, and picture. It means that the reading activities can be provided to the students in some forms through a mobile phone. The reading text may not longer, so the students can read it easily.

Reading activities on WhatsApp group are used for improving students' reading comprehension which is already learned in the class, give real-life materials to the students like a joke, short article, video, audio, and photo. It means that this activity does not change extensive reading in the classroom into WhatsApp group activities. Other utilizations of these activities are it is able to be accessed anytime and anywhere.

Besides that, there are some ways to apply WhatsApp in ELT (English Language Teaching) classroom. They are(Alderman, 2017):

1. Encourage Collaboration

Supporting students to collaborate in a group outside class is one of the ways to avoiding time-consuming in a collaborative task at the class. It should organize well to make it run successfully.

WhatsApp group is a way to encourage students' collaboration outside the class without taking a lot of time and build close space among student to other students, students to the teacher. It is able to be assessed by the students and the teacher everywhere and every time. 
Using WhatsApp group create easy communication to discuss the materials. The students have been familiar with sharing information using WhatsApp through messages, videos, audios, photos, or screenshots. It is very useful for the students and the teacher in creating learning collaboration using WhatsApp messenger outside the class.

\section{Extend Learning Time}

Teaching in limited time make the teachers think how to cover the large task to the students in enough time. Iranian teacher faces it by applying WhatsApp for additional learning time outside the class. He applies WhatsApp group to distribute writing and speaking task to the students regularly. It is because the students should practice their productive skills besides receptive skills.It is very useful to increase students' motivation to practice the skill outside the class and in a familiar environment freely.

\section{Manage Large Class Sizes}

Having large class students make the teacher get difficulty in giving feedback to all students with limited time. An elementary school teacher, Yassir El Hajel Sheikh, has been tried a way to solve this problem. He applies a WhatsApp group as a learning media. He asks the students to record voice messages and then sends it to the group, listen to the voice messages and comment it. Teachers' feedback is very important to let them know about grammar errors, words choice, and spelling in the task.

\section{Flip the Classroom}

Apply WhatsApp group to flip our classroom for giving more quality teaching time in the classroom. The teacher can use classroom time to discuss a necessary topic and its content, giving detail explanation and example. One of the ways to flip the classroom using WhatsApp is sharing videos link through WhatsApp to the students like what the Neusa Pretzel do in her classroom. She shares the video link via WhatsApp and asks the students to watch it before class, ask and answer the question which is related to the video in WhatsApp group.

\section{Build Confidence}

Applying WhatsApp in teaching and learning are able to increase students' confidence and attitude in learning. Like Mauricio Vidal Gheiler's finding that his students be more active to communicate when they apply WhatsApp. Not only that, students' confidence to communicate using WhatsApp is influencing them in the class.

Based on the explanation above, the steps to use WhatsApp in teaching reading comprehension as follows:

a. Setting the rules

The important thing in using WhatsApp is introducing the rules to the students. By introducing the guideline, it will help the students know about our expectation to them. The teachers have to introduce WhatsAppMessenger as a learning media to the students in the first meeting. The guideline is so important for the students in doing their task, project and they can know how they will be assessed at the time. 
The rules of using WhatsApp group in reading activities are very easy. They are:

1. Having a WhatsApp group.

2. Every student has to speak English no mother tongue.

3. Using good words with correct grammar and spelling in doing reading activities.

4. Respecting other opinions

5. The task should be related to reading activities. It can be in the form of a document, electronic document, audio, video, and so on.

6. Responding the task, project, and exercise in the discussion hours. The respond is able in the form of an answer, suggestion, comment, an opinion that is followed by a reason.

7. Getting teachers'feedback

b. Creating a class group using a unique name

After introducing the guideline, the teacher and students have to create a WhatsApp group for a class. All students and the teacher should be the group members. Creating a unique name is one of the ways to get students' interest in usingWhatsApp group for discussing task, project, homework, and exercise. Try to use the WhatsAppgroup with students to help them understand about the learning process on WhatsApp group.

c. Starting reading activity

Star the activities by giving task, exercise, or homework which is related to the topic. Give them clear instruction onhow to do the activities to avoid miscommunication or misunderstanding. Example: share a reading text document or screenshot about the description of Tembilahan city. Ask the students to find out the topic, characteristics of Tembilahan city, a location of Tembilahan city, and the last instruction is asking them to conclude the reading text.

d. Giving feedback.

The teachers have to give feedback by responding to students' answer and opinion. Let them know the result of their work to improve and revise it to be better in the next project or task.Give reword to the best students like get score A, spirit and motivation for others students to improve their skill in reading.

Therefore, the teacher is able to apply WhatsApp messenger in various ways in teaching reading comprehension. Teaching reading comprehension via WhatsApp messenger can increase students' interest to read the text. It increases students' reading comprehension too. The students are interested in using WhatsApp to get reading skill rather than a printed document or book. They are happy using WhatsApp to share information, task, homework, video, audio, picture, clearing problems outside the class, losing their boring in reading. WhatsApp can be used in education and can develop students' reading skill(M \& Kanchana, 2016). 


\section{CONCLUSION}

WhatsApp messenger can be used as a learning media besides as a communication tool. It makes the teacher and the students are easy to communicate and discuss reading material before going to the class to improve students reading comprehension. WhatsApp is very easy and cheap to apply in teaching reading comprehension because the students have been familiar with WhatsApp. The steps using WhatsApp in teaching reading comprehension are setting the rules, creating a unique name for WhatsApp group, star the reading comprehension activity, and give them feedback.

\section{BIBLIOGRAPHY}

Alderman, S. (2017). 5 Ways to Use WhatsApp in the ELT Classroom. Pearson English. Retrieved July 10, 2018, from https://www.english.com/blog/5-ways-usewhatsapp-elt-classroom/

Biancarosa, G., \& Griffiths, G. G. (2012). Technology Tools to Support Reading in the Digital Age. Future of Children, 22(2), 139-160.

Bouhnik, D., \& Deshen, M. (2014). WhatsApp Goes to School: Mobile Instant Messaging between Teachers and Students. Journal of Information Technology Education: Research, 13, 217-231.

D'Eca, T. A. (2003). The Use of Chat in EFL/ESL. Retrieved July 9, 2018, from http://www.tesl-ej.org/wordpress/issues/volume7/ej25/ej25int/

George, M. S. (2018). Developing Listening and Reading Skills through Social Media using Apps. Literary Studies, III(i), 93-101.

Jumiatmoko. (2016). WhatsApp Messenger dalam Tinjauan Manfaat dan Adab. Wahana Akademika, 3(1), 51-66.

Justina, M. (2016). Use of Whatsapp to Enhance Reading and Writing Skills at Undergraduate College Level. Language in India, 16(11), 47-60.

Kheryadi. (2017). The Implementation of "Whatsapp" as A Media of English Language Teaching. LOQUEN, 10(2), 1-14.

Khusaini, Suyudi, A., Winarto, \& Sugiyanto. (2017). Optimalisasi Penggunaan WhatsApp dalam Perkuliahan Penilaian Pendidikan Fisika. JRKPF UAD, 4(1), 17.

Linse, C., \& Nunan, D. (2005). Practical English Language Teaching: Young Learners.

M, M., \& Kanchana, K. (2016). A Study on Developing Reading Skills of Engineering Students through WhatsApp as Motivational Strategy. International journal of english research, 2(3), 1-4.

Pyrhonen, H. (2018). Reading Today: Comparative Literature and Culture. In H. Pyrhonen \& J. Kantola (Eds.), New Perspectives on Reading: An Introduction (pp. 1-199). London: UCL Press.

Santrossa, C., \& Castillo, J. (2017). No Title. Learning Technologies Special Interest Group. Retrieved July 10, 2018, from https://tsig.iatefl.org/whats-up-in-theclassroom-whatsapp/

Scanlon, D. M., Anderson, K. L., \& Sweeney, J. M. (2010). Early Intervention for 
Reading Difficulties: The Interactive Strategies Approach. New York: The Guilfrd Press.

Snow, C. E. (2002). Reading for Understanding: Toward an R\&D Program in Reading Comprehension. New York: Rand.

Sugiyono. (2015). Metode Penelitian Kuantitatif, Kualitatif dan $R \&$ D. Bandung: Alfabeta, cv. 